above this line, and seemed to be unaccountably out of place. $\mathbf{A} s$, bowever, the moon was little past the first quarter, and the terminator nearly a straight line, and only slightly inclined from the vertical, a line drawn perpendicular to it would have passed through the lefr-hand patch, and I imagine that its position was due to this inequality in shape of the two sides of the visible moon. The atmosphere was hazy, the moon though clearly visible appearing as in a slight fog. No colours were distinguishable at any part of the halo.

Birstal Hill, Leicester, April 17

\section{Benevolence in Animals}

Two or three years ago Dr. Allen Thomson gave me an instance of benevolence in a cat which is so closely similar to one communicated to you by Mr. Oswald Fitch that for the sake of corrohoration I may state it.

The cat belonged to Dr. Thomson, and one day came into the kitchen, pulled ihe cook by the dress, and otherwise made signs showing a persi tent desire to attract attention. Eventually the cat led the cook out of doors and showed her a famishing stranger cat. The cook thereupon gave the stranger some food, and while this was heing discussed, Dr. Thomson's cat paraded round and round her companion, purring londly with a satisfied sense of well-doing.

GEORGE J. ROMANES

\section{"Medioscribed Circle"}

IN this week's NATURE (p. 595) the use of the medioscribed circle is -u vaested in place of the well-known "nine-point" circle. If a change is desirable, would not " mid-point " circle be equally expressive?

April 20

$$
\text { AGRICULTURE IN MADRAS } 1
$$

THE Government establishment at Saidápet has now been in existence about twelve years. It consists in part of an experimental farm, and in part of an educational establishment, in which, at the date of the last report, forty-one native students were receiving instruction in the science and practice of agriculture. The whole is under the superintendence of Mr. W. R. Robertson. The object in view is to improve the condition of agriculture in the Presidency. This is indeed urgently needed. With a large and increasing population, the soil is in general wretchedly cultivated, and reduced to a low state of fertility. The farm at Saidápet is the centre of many useful agencies. Here new crops, new breeds of cattle, and improved implements are carefully tried. Here the teaching of European science is reduced to practice, and methods of cultivation suitable to the conditions of Indian agriculture are perfected. While by means of the educational department by tours in the country, distributions of seed, ploughing competitions with different implements, and various other agencies, the endeavour is made to bring these improved methods into use by the native farmers.

The meteorological records kept at the farm exhibit in a striking manner the difficulties under which Indian agriculture must be pursued. Thus in the season $1880-81$ the rainfall in September was $10^{\circ} 9$, in October $10^{\circ} 7$, and in November 19.6 inches, while during the whole six months from January to June only 2.35 inches were recorded. I,ong-continued heat and drought are thus followed, on the arrival of the monsoon, by a deluge of rain. It is pleasing to notice that the director of the farm is quite abreast of the latest scientific teaching respecting the be-t mode of meeting the difficulty in question. It is plain that in the rainy season the land will be washed clear of all soluble plant-food; all nitrates formed in the soil during the hot season will thus be lost, unless they have been alrearly assimilated by a crop. Mr. Robertson recommends that, whenever possible, advantage should be taken of the first commencement of rain in June or July to sow the land with a green leguminous crop (horse-

I Annual Reports on Government Agricultural Operations in the Madras Presideacy, $1880-8 \mathrm{r}$ and $\mathrm{r} 88 \mathrm{r}-82$. gram). In most years there will be enough rain to maintain such a crop in growth during the summer months. This crop will collect and assimilate a great part of the nitrates in the soil. At the commencement of the wet season the green crop is to be ploughed into the soil, and forms an excellent manure for the principal crop of the year, which is then sown. Mr. Robertson refers apparently to the experiments at Rothamsted when speaking of the quantity of nitrates annually formed in a soil; the amount he mentions (4o lbs. of nitrates ${ }^{1}$ per acre) is, however, far below the truth. The quantity of nitrates found in five successive years in the drainage water from uncropped and unmanured land at Rothamsted amounts, indeed, on an average, to nearly 3 cwts. of Indian saltpetre per acre per annum.

In India agriculture depends much for its success and permanence on irrigation, and vast sums have been, and will be, expended on irrigation works. Here again, however, the question of the presence or absence of nitrates is an important factor, which has been almo it entirely overlooked, engineering rather than chemical skill having been employed in the direction of the work. It should always be borne in mind that a water containing nitrates supplies not only water but manure. The native farmers are generally quite aware of the difference in value of different water-supplies, and reckon the water from the village well as worth far more than that prosured from the Government canal. To the engineer it appears a ridiculous waste of power to lift water from a well when a water-supply is available at the level of the land. But the native is right; bis well-water is rich in nitrates, and for the farmer's purpose far more valuable than the purer water of surface drainage found in rivers and canals. It should always be borne in mind in plans for irrigation, that the drainage from arable land, and from inhabited districts will always yield the best irrigation water. By restoring to land in time of drought the plant-food lost in time of flood we are pursuing a truly scientific economy. R. W.

\section{ANTHROPOLOGICAL NOTES IN THE SOLOMON ISI,ANDS}

WITHOUT going into the general question as to the position which these islankers hold to the other Pacific races, I will briefly state the results of numerous measurements and observations which I made during my visit to these islands in 1882 . As the surveying work of this ship was confined for the most part to the large island of St. Christoval and the adjacent small islands, my remarks will refer more particularly to the natives of this part of the group.

The average height of a man of St. Christoval is about 5 feet 3 inches or 5 feet 4 inches, whilst the span of the arms generally exceeds the length of the body by from 4 to 5 inches. Both men and women are usually of a good physique, robust and well-proportioned; but one may find in the same village community weak, puny, thin-limbed individuals associated with others of a strong muscular frame, with well-rounded limbs and a good carriage.

The colour of the skin varies considerably in shade from a very dark brown, approaching black, to a dark copper hue. The elderly adults are as a rule more darkskinned than those of younger years, the difference in shade being attributable partly to a longer exposure by reason of their age to the influence of sun and weather, and partly to those structural changes in the skin which accompany advancing years. Not infrequently, amongst a group of dark-skinned natives a man may be observed whose skin is of a pale sickly hue, and who at the first glance may be thought to afford an example of recent " Possibly in Mr. Robertson's Report "nitrates" is here a misprint for " nitrogen." 
intermingling between the Melanesian and Polynesian races. On a closer examination I always found that such men were covered from head to foot with an inveterate form of body ringworm-a scaly skin-eruption, which affects in a greater or less degree quite two-fifths of the natives of this part of the group-and that in all their other physical characters they belonged to the Melanesian type. In its most aggravated and chronic condition this parasitical disease implicates the skin to such a degree that the rapid desiccation and desquamation of the epidermal cells lead to a partial decoloration of the deeper parts of the cuticle, as though the rate of the production of pigment was less rapid than the rate of its removal in the desquamative process.

The hair of the head is generally black, frizzly, and bushy; more particularly amongst the younger adults of both sexes this last character prevails. Amongst middleaged men I have som times observed that the hair arranges itself into entangled corkscrew-like spirals,

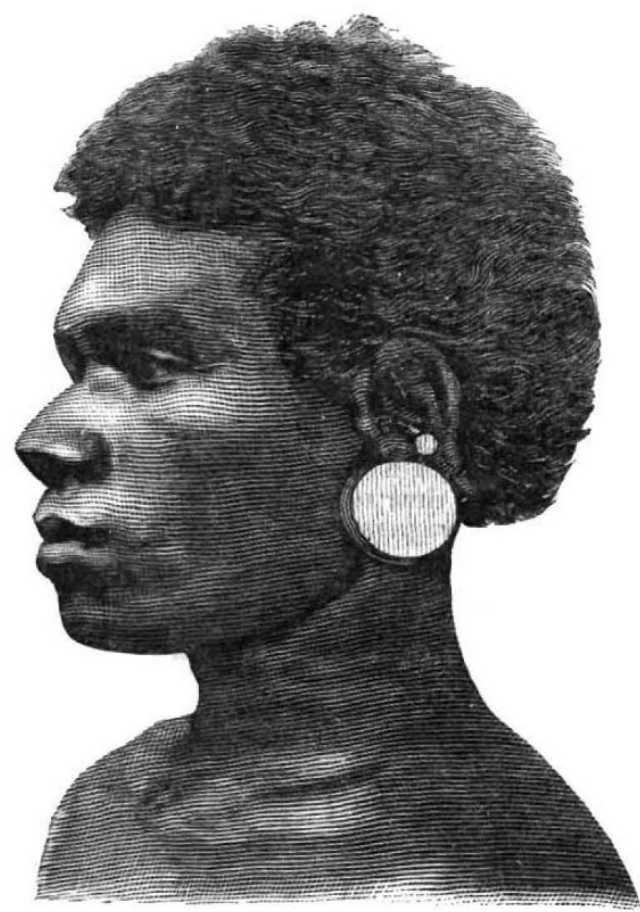

Fig. I.-Native of Santa Anna (an island off the east extremity of St. Christoval). The round disk of w rod in the lobe of the ear should be quite white, the dark sp ts being due to the imperfections of the dry plate. The faint linear

the whole head of hair having much the appearance of a mop placed erect on its handle. Now and then, though rarely, the hair shows a tendency to become straight; I met with one such native near Cape Keibeck, on the north coast of St. Christoval; and I am informed that straight-haired varieties do exist among the hill-tribes in the interior of the island. With regard to the amount of hair on the face, limbs, and body, great diversity is observed amongst natives of the same village. Epilation is commonly employed, but there can be no doubt that the development of hair varies quite independently of such a custom. Out of ten men taken promiscuously from any village, perhaps five would have smooth faces, three would possess a small growth of hair on the chin and upper lip, the ninth would wear a beard, a moustache, and whiskers of moderate growth, whilst the tenth would present a shaggy beard and a hairy visage. The surfaces of the body and limbs are as a rule comparatively free from hair; but hairy men are to be met with in most villages; and on one occasion when in the vicinity of Cape Surville--the eastern extremity of St. ChristovalI visited a village where the proportion of hairy-bodied, hairy-visaged men was in excess of the smooth-skinned element.

From my measurements the form of the skull would appear to be mesocephalic: the cephalic indices ranged between 73 and 82 -the greater number of them being included between 74 and 77 . The facial angle varied in amount between $85^{\circ}$ and $90^{\circ}$. The nose is $\mathrm{g}$ nerally straight, coarse, and somewhat short, the nostrils wide, and the bridge depressed in some instances. Not uncommonly the nose.is arched or aquiline; out of fifty natives amongst whom I took especial notice of this feature, I found that ten possessed an aquiline nose. The countenances of the younger of both sexes are often prepossessing, and amongst the adults I have frequently met with men of some intellectual expression.

Such are some of the leading physical characters of the natives of this part of the Solomon group. To the inhabitants of the small island of Santa Anna, which lies off the east extremity of St. Christoval, the same description will apply; but we find in the still smaller adjacent island of Santa Catalina a subvariety of the Melanesian type characterised by a lighter colour and probably a greater height, although I made no measurements there. The few natives which I saw belonging to the large island of Malayta, which we did not visit, resembled in appearance those of St. Christoval ; and from a few measurements and observations which I made in the Florida subgroup, where the St. Christoval type prevails, it was evident that thus far to the westward the same description of a native of the Solomon Islands was equally applicable. The large neighbouring island of Guadalcanar I had no opportunity of visiting. In the small island of Simbo, further to the west, I found no important difference in the physical characters of the natives except perhaps a rather darker shade of colour. Proceeding westward as far as Treasury Island, our furthest point in that direction, we for the first time came upon a distinct variation in the type of native-a difference which has been a subject for remark even by such usually unobservant people as the masters of trading ships. In their greater height and in the ahnost black colour of the skin, the natives of Treasury Island are at once distinguished from the prevailing native type to the eastward. Their features are more finely cut, and the form of the skull, as shown by the cephalic indices, is more brachycephalic-the range of seven measurements being 78 to 84 , and the mean cephalic index 8I. In some individuals the cheekbones were prominent and the forebeads retreating. As a race the Treasury Islanders are said to evince a fiercer disposition than do the natives in the eastern islands of the Solomon group. The natives of the large adjacent island of Bougainville have the reputation of being amongst the most daring and warlike of the inhabitants of this archipelago ; and probably the examination of their physical characters will exhibit them as a more pronounced type of the Treasury Islanders.

H.M.S. Lark, Auckland, N.Z., February 27

ON A FINE SPECIMEN OF APATITE FROM TYROL, LATELY IN THE POSSESSION OF MR. SAMUEL HENSON

$T \mathrm{HE}$ specimen of apatite represented in the diagram was submitted to my inspection by Mr. Henson last November, and is the most beautiful specimen of this mineral which I have seen. The faces observed were not, however, determined on the specimen itself, but from a plaster cast and a smaller specimen with which $\mathrm{Mr}$. Henson supplied me. From these latter approximate measurements of some of the more prominent angles were obtained by means of a contact-goniometer, which, 